\title{
The Philosophy of Perceiving the Human Environment from the Perspective of Environmental Social Psychology and Environmental Sociology (Implications for Sustainable Environmental and Health Security)
}

\section{Filozofia postrzegania środowiska człowieka z perspektywy społecznej psychologii i socjologii środowiskowej (implikacje dla zrównoważonego bezpieczeństwa środowiskowego i zdrowotnego)}

\author{
Mariusz Ciszek \\ The Department of Humanities, The Jacob of Paradies University, \\ ul. Teatralna 25, 66-400 Gorzów Wielkopolski, Poland \\ E-mail:m.ciszek.contact@gmail.com \\ ORCID: 0000-0003-0294-3048
}

\begin{abstract}
Environmental issues constitute more and more eagerly undertaken scientific issues. It is probably due to the contemporary situation, in which the threats to the environment inhabited by people are increasing. Importantly, the problems of this type are not only examined within the framework of environmental or ecological sciences but also the social sciences and humanities. There is nothing strange about it; after all, the society in which a person lives is a crucial element of the human environment. Every person's life takes place in a particular environment, the state of which affects people, their psychophysical health and well-being, the fulfillment of life necessities, behavior, and functioning in society. Such issues are discussed within the framework of environmental social psychology and environmental sociology. This article is devoted precisely to these disciplines. The publication briefly presents the essence of these environmental social sciences (starting from the characteristics of environmental social psychology, and then moving to environmental sociology). However, their essence was shown from the perspective of a specific, concise philosophy (vision) of perceiving the human environment that can be found in these social sciences. The human environment can be understood in various ways, not necessarily coinciding with what is considered the environment in natural sciences. This vision of perception of the human environment in the publication is a useful criterion for the interpretation and division of these disciplines into two basic variants - traditional (typical humanistic and social, currently applicable) and postulated model (socio-natural). It is also able to guarantee sustainable environmental (ecological and health) security.
\end{abstract}

Key words: environmental social psychology, environmental psychology, environmental sociology, philosophy of environment, human environment, environmental (ecological) security, health security

\section{Streszczenie}

Zagadnienia środowiskowe to coraz chętniej podejmowana obecnie problematyka naukowa. Wynika to zapewne ze współczesnej sytuacji, w których zagrożenia dla zamieszkiwanego przez ludzi środowiska są coraz większe. I co ważne tego typu problemy badane są nie tylko w ramach nauk środowiskowych czy ekologicznych, ale również w obrębie nauk społecznych i humanistycznych. I nie ma w tym nic dziwnego, przecież społeczeństwo, w którym żyje człowiek, to ważny element ludzkiego środowiska. Życie każdego człowieka przebiega bowiem w pewnym środowisku, którego stan oddziałuje w odpowiedni sposób na ludzi, ich zdrowie psychofizyczne i samopoczucie, 
realizację potrzeb życiowych, czy zachowanie i funkcjonowanie w społeczeństwie. Tego typu zagadnienia podejmowane są w ramach społecznej psychologii środowiskowej i socjologii środowiskowej. Właśnie tym dyscyplinom poświęcono niniejszy artykuł. W publikacji przybliżono zwięźle istotę tych środowiskowych nauk społecznych (poczynając od charakterystyki społecznej psychologii środowiskowej, a następnie przechodząc do socjologii środowiskowej). Natomiast ich istotę ukazano z perspektywy pewnej zwięzłej filozofii (wizji) postrzegania ludzkiego środowiska, jaką można odnaleźć w tych naukach społecznych. Środowisko człowieka bowiem może być różnie rozumiane, niekoniecznie zbieżne z tym co za środowisko uznaje się w naukach przyrodniczych. Owa wizja postrzegania środowiska człowieka stanowi w publikacji użyteczne kryterium interpretacji i podziału tych dyscyplin na dwie podstawowe odmiany - tradycyjną (typowo humanistyczno-społeczną, obecnie obowiązującą) oraz na model postulowany (społeczno-przyrodniczy). Jest on w stanie zagwarantować również zrównoważone bezpieczeństwo środowiskowe (ekologiczne i zdrowotne).

Słowa kluczowe: społeczna psychologia środowiskowa, psychologia środowiskowa, socjologia środowiskowa, filozofia środowiska, środowisko człowieka, bezpieczeństwo środowiskowe (ekologiczne), bezpieczeństwo zdrowotne

\section{Introduction}

Environmental issues are currently one of the main problems of the modern world. Issues related to the functioning and proper shaping and use of the environment, previously reserved for sciences in the field of environmental protection and ecology, penetrate social sciences and humanities. And so they should. Nothing stands in the way for socio-humanistic issues to also penetrate back into ecological and environmental sciences, appreciating the importance of psychosocial conditions that shape the human environment. This approach will be applicable in this article, in which the human environment will be treated and interpreted much more broadly. Not only as a natural environment (as naturalists often do), or a narrowly understood social or socio-cultural environment (as perceived by the representatives of environmental social psychology ${ }^{1}$ and environmental sociology) but also as a systemically related, holistic socio-natural environment.

At the same time, the article recognizes that the human environment, in addition to its socio-cultural component (i.e., artificial, built on nature transformed by people), also includes a closely related natural environment (being a product of nature), creating a total natural environment of human life. Therefore, environmental and natural issues may be of interest to social sciences and humanities, and especially environmental social psychology and environmental sociology, on which this article is focused.

The publication also refers to some extent to the philosophy of the environment, although in a broad sense, showing only a particular philosophy (vision) of a balanced perception of the human environment. Therefore, it is an approach that tries not to create unnecessary threats in the human environment, consisting in maintaining a state of relative and dynamic

\footnotetext{
${ }^{1}$ This environmental branch of social psychology is sometimes also called social environmental psychology (Bańka, 2002 - as translated and cited in: Bielak, 2012, p. 7, 16). Although this expression seems to be more linguistically accurate, this article replaces it with the term more often
}

balance between the natural environment and the human socio-cultural environment. This balance should be considered as a desirable state of environmental (ecological) and health security, positively shaping people's living environment and optimally affecting their psychophysical well-being, naturally, while maintaining a good state of nature (and thus in the spirit of sustainable development).

\section{The concept of the environment}

There is no doubt that human life, all life processes, and activities, individual (biological) as well as socio-cultural development and activity, always take place within some environment (Bańka, 2002: 19). The concept of the environment, which was introduced into the scientific language through ecology, and thus identified with the natural environment, is now also used in a context other than typically biological one and also functions in social sciences, humanities, and other sciences, as well as in everyday language (e.g., social or cultural environment, work environment, etc.). In general terms, environment can be defined as the totality of (closely interrelated) elements, phenomena, processes and material (animate and inanimate) and immaterial (e.g., social or cultural relations) factors, both natural and anthropogenic, occurring in a specific space, creating the combined environment and living conditions of individual organisms (e.g., Mazurski, 2009: 260; Olaczek, 1999: 249). Such a definition can be clarified by replacing the word individual with the word human, and then we have a definition of the human environment, which in the case of people is a socionatural environment.

In the case of the natural environment - in the definition presented above - it includes living (biotic) and non-living (abiotic) components of nature. The former creates a biological environment (composed

used in international mainstream (and scientific literature): environmental social psychology (e.g., Canter, 1988; Sabourin and Lamarche, 2009). Both terms can be used interchangeably. 

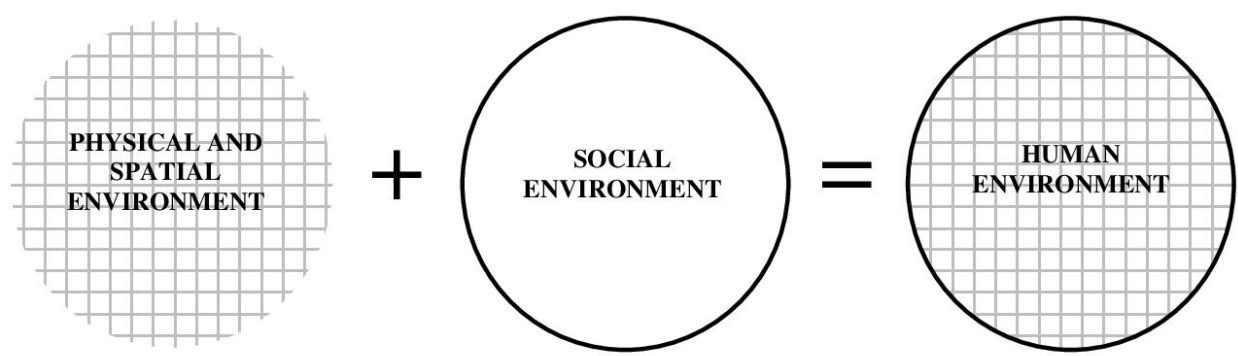

Figure 1. Human environment in terms of environmental (social) psychology, source: author's own study

of organic matter, organisms, living), and the latter physical one (composed of elements of inanimate matter; physicochemical; dead, a habitat for living organisms). However, in the case of the human environment, these are not only natural, material, and spatial elements, but also people in different relations with each other and with the things that surround them (socio-cultural environment) (Bańka, 2002: 19).

Therefore, we are dealing here with a socio-natural (or more specifically socio-cultural-natural) environment of the broadest and complex dimensions, because it integrates with itself various types of environments, consisting not only of natural but primarily of social and cultural components constituting the material and immaterial effects of human activity. These include, for example, people and their behavior, social institutions and groups, cultural elements (e.g., norms, values, beliefs, ideas) as well as objects constituting the product of human activity (e.g., Olechnicki and Załęcki, 2002: 214). The latter is located in the appropriate physical (material), designed, transformed space built up by people, adapted to their needs (physical and spatial environment, physical and spatial surroundings; physical and spatial environment).

\section{Problems of the human environment in terms of environmental social psychology and environ- mental sociology. From traditional socio-human- istic to socio-natural interpretation}

Nowadays, natural environment issues are increasingly exposed in social sciences. On the one hand, this results from the ecological crisis of the modern world and attempts to repair such an unfavorable state of affairs. On the other hand, from an absolute fact that human life, both in its individual and social dimensions, always takes place within some environment. When it is shaped in a certain way, it can positively or negatively affect a person. It especially concerns human well-being, psychophysical health, the fulfillment of life needs and activities, supporting the development or degradation of human behavior - as pointed out by environmental psychologists (Bańka, 2002: 25) - and the proper functioning of a human being in society (which is the domain of environmental sociology).
Here, it is worth to briefly introduce the essence of these two environmental disciplines in the field of social sciences (starting from environmental social psychology, and then moving to environmental sociology, because the boundaries between them are quite fluid). However, their essence will be shown from the perspective of a concise vision (philosophy) of perceiving the human environment present in these social sciences. This approach to the human environment will be a useful criterion for the interpretation and division of these disciplines into two primary varieties - traditional (typically humanistic and social and, in principle, currently applicable) and the postulated (socio-natural) model - of a systemic or holistic nature, having a significantly broader humanist-ecological dimension of a biosocial character.

Given this criterion, environmental psychology can be interpreted in a narrower or broader perspective. It is perceived in different ways (e.g., Stokols and Altman, 1987; Bell, Greene, Fisher and Baum, 2001; Bańka, 2002; Steg, van den Berg and de Groot, 2012; Gifford, 2014). In general, it is defined in this first aspect as a psychological discipline examining the relationships between a human being and the physical (physical-spatial) and social environment (Bańka, 2002: 25). This type of understanding of this branch of psychology is dominant so that it can be considered as a binding model of perception of environmental psychology. According to this approach, the human environment is perceived as a physicalspatial (material-spatial) environment built (or transformed) by people, constituting the basis for a social environment, conditioned psychosocially. The physical environment is a habitat for society, but it is also an active element, affecting the human psyche and society. The human environment is simply a physical and spatial environment plus a social environment (see Fig. 1). However, there are interactions between these two components of the human environment (physical and social), because they are not passive but active. Consequently, they both shape the human psyche.

Currently, in the context of environmental psychology understood in this way, various - already recognized - psychological and ecological concepts (usually by James J. Gibson or Roger G. Barker) are used. Furthermore, although they differ fundamen- 
tally, they do not have to be mutually exclusive (Bańka, 2002: 81-83). Their common feature is that they emphasize natural and naturalistic (that is, real) studies of human behavior in the natural environment in which people live, in contrast to the artificial environment (e.g., laboratory or abstract space). The natural environment understood in these concepts is not, however, the equivalent of a natural environment (animate and inanimate), as is the case directly in natural ecology or biology, or materialspatial or physico-chemical elements of the environment studied by physicists or chemists (Lubiszewski, 2012: 268). Depending on the concept, it can mean any real environment in which a particular person lives (e.g., the large-city environment of a resident of the capital - e.g. Gibson, 1972, 1977, 1979), or - in terms of methodology (e.g., Gifford, 2016) - an environment free of the researcher's influence (e.g. Barker, 1968, 1978, 1987). In psychological and ecological concepts, it is generally assumed that the true human psyche and behavior are an inseparable part of the environment (it becomes present in interactions with the environment), and to understand them we need to know the environment of human life in which a person is embedded (Bańka, 2002: 81-83) - see footnote 2.

However, there are no obstacles to understanding and interpreting environmental psychology much broader than before. What is more, one can add the natural environment, in addition to the physical (physical-spatial) and social environment, to its research subject. Environmental psychology understood in this way could then be defined as a psychological discipline examining relationships and connections between a human being and the physical (physical and spatial), natural and social environment of his/her life (own definition). According to this approach, environmental psychology, in addition to the social environment mentioned above, would include the combined effects of the bio-physical environment (natural and physical-spatial) on humans - including their behavior and psyche.

Psychology perceived in this way; some authors may consider ecological psychology ${ }^{2}$ understood in the biosocial sense (for it includes natural influences on

\footnotetext{
${ }^{2}$ One may encounter the name ecological psychology as opposed to environmental psychology (but often for a reason other than the one indicated above). This type of approach does not have to be wrong, and is acceptable, but only if one first define or strictly explain the understanding of the first expression, which may be used by various psychological schools. Otherwise, it can lead to misunderstanding. The concept of ecological psychology - as a proper name - includees at least two psychological orientations. This name is always referred to as the ecological theory of perception of James J. Gibson, and usually also the ecobehavioural concept of Roger G. Barker (although the name of environmental psychology in the case of the latter scientist is also used in psychological terminology). As already noted, the adjective ecological used in their
}

the physical and social environment of a human being) and distinguish it from environmental psychology (not including issues regarding the impact of nature on a human being). Accordingly, ecological psychology, as opposed to an environmental one, would cover the issues of the natural human environment, while the latter version of psychology - only the physical (physical-spatial) and social environment. Such a distinction is, however, quite artificial and debatable because currently in the scientific literature in the field of humanities and social sciences there is a tendency to replace the adjective ecological with the term environmental or to use them interchangeably (even in the names of individual sub-disciplines), e.g., ecological ethics - environmental ethics, ecological philosophy - environmental philosophy. The environment can have various dimensions, including both natural and non-natural aspects (physical, social, cultural, etc.). The concept of the environment in social sciences has, moreover, been adapted from natural sciences (biological, ecological), and the natural environment of human life includes both natural elements (creations of nature) and artificial elements that are products of human activity. Therefore, one can use the concept of environmental psychology in a broader sense and also mean natural (biological) areas of the human environment, next to those of a physical (physical-spatial) and social nature ${ }^{3}$.

The above-mentioned environmental psychology (especially according to a narrow non-natural approach) is often combined with the tradition of social psychology (a discipline found where psychology and sociology meet, which investigates mental processes and the behavior of people in social situations, Koger and Winter, 2010: 95-130). Hence the term environmental social psychology (Bańka, 2002; see footnote 1). The subject of interest in the environmental branch of social psychology is focused on the physical and spatial factors of the environment, socio-cultural factors, as well as mutual interactions and relationships between them. Studies of environmental social psychology understood in this way cover three areas. The first relates to the impact on the human psyche and behavior of physical and spatial representations of the environment (such as

names (and theories) largely coincides with the adjective environmental (in practice identifying the semantic meanings of these terms in a sense characteristic of traditional environmental psychology). The understanding of the human environment within the fields of ecological psychology is also no different from that developed within (narrowly understood) environmental psychology. For this reason, varieties of ecological psychology can be treated as trends in contemporary environmental psychology.

${ }^{3}$ However, this does not change the fact that in the strictly scientific sense, the use of the name of ecological psychology would be fully justified if these connections between people and their physical and socio-natural environment were studied using the knowledge of modern ecology (biology). 
sound, shape or space), taking into account the shortterm adaptive effects of such impacts on the life of the individual and entire human groups or larger communities. The second research area focuses on the factors of the physical and social environment influencing self-esteem, well-being or sense of development, identity, control over the environment, and freedom of action. The third area covers the issues of practical applications of psychological knowledge regarding human functioning in the environment (and its individual dimensions), especially in the aspect of health protection, work, education, development, recreation, politics, etc. (Bańka, 2002: 26). Some psychologists within this area (or these areas) may also take up some issues in the field of the natural environment and its protection, e.g., in the context of the impact on a human being of contamination, pollution, devastation, disasters or other adverse factors. However, they are most often interested in the designed environment, constituting a socio-cultural product of a human being (Bańka, 2002: 19). It happens because a human being does not appear directly in the natural environment (unaltered, primary).

However, there is nothing to prevent one from adding and to these factors and emphasizing the natural factors of the environment that affect people, both in individual (on their psyche, personality, psychophysical health, also shaping behavior and attitudes towards the environment and ecological awareness, etc.) as well as collective dimension, through the groups or communities people co-create in the areas mentioned above. A human being is organically related to nature, and in this way, one supplements and links environmental social psychology with its socio-natural version (or natural and social version). Such an interdisciplinary supplement is also possible since in social psychology, within its theoretical approaches, the evolutionary trend is used (although it is less popular), and it takes into account biological and cultural conditions (in explaining social behavior of people like the effect of biological and cultural evolution).

Nowadays, there are various varieties of environmental psychology, understood and called in many ways (e.g., ecopsychology), which is only at the stage of shaping. These varieties study the impact of nature on the development of the human personality, psyche, and emotional sphere. They also emphasize human interdependence with nature and strive to rebuild ties with it and maintain positive relationships (Ciszek, 2013: 32; Winter, 1996). These are necessary for people to be able to feel happiness, develop properly, and shape their psychophysical health. Separation of a modern human being as well as, in a broader dimension, detachment of the social environment from nature leads to many fears, addictions, and other mental problems. In the social dimension, it can translate into disruptions to the functioning of entire communities. Such considerations and re- search could be included in the broadly understood, interdisciplinary environmental social psychology. Currently, there is a noticeable trend of approaching environmental social psychology to environmental sociology. It results, for example, from the fact that nowadays, the boundaries between social psychology and sociology are becoming more fluid. Traditionally - referring to the classic psychological literature - it is pointed out that the fundamental difference between social psychology and sociology lies in the fact that psychology examines an individual in a group. In contrast, sociology focuses on the group as a whole (Allport, 1924: 10). It can be said that social psychology examines a human being in society, while sociology - a society in a human being (social aspects or elements present in the individual - a social being). At present, however, in practice, such relationships and conditions often overlap and interact with each other. These peculiarities are also evident in the aspect of already described environmental social psychology and environmental sociology, which is worth discussing below.

Environmental sociology, unlike traditional environmental social psychology, directly covers issues related to the natural environment of people, examining socio-environmental interactions in sociology, using its theoretical positions and methods. This branch of sociology is generally defined as a sociological discipline that studies the interactions between the environment and society (Catton and Dunlap, 1978: 44; Bowden, 2017: 2). The social environment could also include its material physical and spatial environment created by people. Then one could say that environmental sociology is a sociological discipline examining relations, dependencies, and relationships between the individual and the social, physical, and spatial, and natural environment of his/her life (own definition). As part of these interactions, the impact of the natural environment on society is recognized. Although the main subject of its interest is the general relationship between society and the environment, environmental sociologists particularly emphasize the study of social factors creating environmental problems and their social effects and efforts to solve them.

Also, in this type of detailed sociology, much attention is paid to the environmental conditions of specific social processes that can cause social problems (e.g., Matczak, 2000, 2001; Czartoszewski, 2003). These relations between society and the environment can also be undertaken within specific institutions and structures or subsystems, such as law, culture, economy, politics, as well as group behavior (society's attitudes towards the environment, the state of ecological awareness, consumption, etc.), showing their relationships with environmental conditions and possible consequences related to it (e.g., environmental consequences of waste disposal and recycling or the impact of environmental conditions on people's lives in their place of residence, work, life- 
style, or public health, etc.) (e.g., Redclift and Benton, 1994; Schnaiberg and Gould, 1994; Martell, 1994; Irwin, 2001; Redclift and Woodgate, 2010; Gross and Heinrichs, 2010; Hannigan, 2014; King and McCarthy Auriffeille, 2014; Gould and Lewis, 2015; Burns and Caniglia, 2015; Bell and Ashwood, 2016; Carolan, 2017; Cole, 2017).

These numerous socio-environmental relations are usually studied by researchers and theoreticians of this discipline in the following currently popular thematic areas (Cole, 2017):

- Climate change - the human, political, and economic causes of these changes and their impact on people, and especially on specific aspects of social life, such as behavior, culture, lifestyle, public communication and transport, the health of human populations, and other effects of such interactions.

- Economy and the environment - it is particularly relevant here to study the relationship between the economic model of a given society (state) and the environment (and climate change referred to above), especially in the context of the acquisition and recovery of natural resources in production processes and methods (e.g., between a capitalist economy based on continuous growth or a sustainable model that results in an appropriate state of the environment);

- Energy and the environment - this type of relationship results from the previously mentioned areas; the relationship between fossil fuel combustion in the energy industry as a significant factor in global warming and climate change is evident here. One could notice the impact of the economic model on these adverse changes (e.g., coal-based economy). Not without significance is the ecological awareness of specific populations and their ideas affecting the appropriate behavior and attitudes of people towards energy consumption, as well as the impact of energy policies that shape behavior and the state of the environment.

- Politics, law, and public policy, in the context of relations with environmental conditions and problems - institutions and structures shaping corporate and individual behavior having an indirect impact on the state of the environment are taken into account. Within this area, sociologists are also trying to determine by what mechanisms laws regulating emissions and pollution are enforced, their scope of influence, and how people work together to shape them. Also examined here are forms of power that may favor or hinder society in this field.

- Social behavior and the environment - the relationship between various social behaviors that shape the state of the environment is examined, as well as how environmental conditions shape social behavior. The following issues are cur- rently particularly popular in sociological research:

- consumption - in this area there is a significant convergence between environmental sociology and the sociology of consumption, since consumer behavior, and especially consumerism, may cause various types of problems for the environment; proper shaping of consumer attitudes can also contribute to beneficial solutions that improve environmental conditions;

○ transport, household energy consumption, waste management, and recycling are issues that also translate into an appropriate state of the environment.

- Inequality and the environment - sociologists pay attention to the manifestations of various types of social inequalities and their relationship with environmental issues. Their research shows that income, racial, and gender inequalities (especially environmental racism) mean that specific populations that experience them more often are more likely to experience the adverse effects of a degraded environment, such as pollution, proximity to waste, and lack of access to natural resources. Reactions of specific populations and institutions are also examined here, as well as in the global perspective of entire populations within individual nations, to their different relations with the environment, in case they are somewhat privileged and well-off.

In addition to the above (Cole, 2017), one can also add (or separate and clarify) other areas, e.g.:

- Activity for the environment and environmental awareness - social activity within (or for the benefit of) environmentally friendly non-governmental organizations, associations, etc., or in informal arrangements that aim to protect the environment and shape positive attitudes towards nature and its elements, and to promote knowledge about the environment; as well as research into people's ecological awareness.

- Social institutions and the environment - a section covering the institutional dimension of environmental protection, concerning the activity and functioning of social institutions responsible for the state of the environment and its security.

From the analysis of the areas (sections) presented above, it can be concluded that environmental sociology exceeds traditional environmental psychology (its narrower interpretation), approaching its postulated extended version. Previously practiced environmental psychology could also be interested in the natural environment, in the context of some unfavorable factors for human health and life, stemming from the destroyed nature, although it mainly focused on the physical (physical and spatial) environ- 

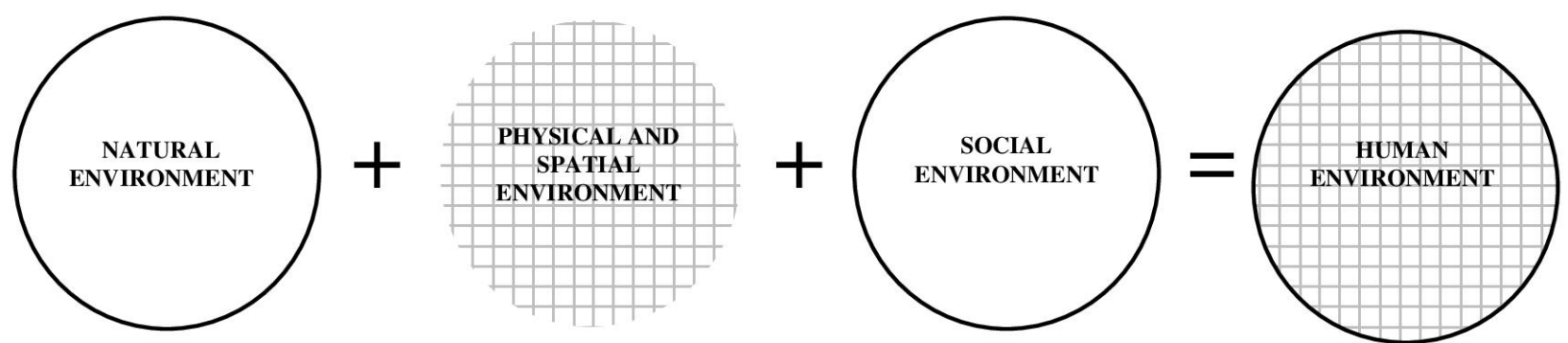

Figure 2a. The human environment in terms of traditional environmental sociology, source: author's own study
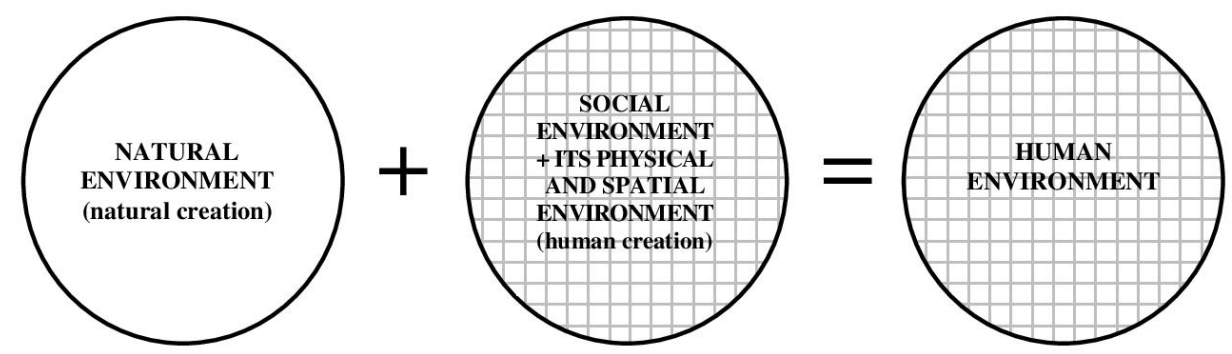

Figure $2 \mathrm{~b}$. The human environment in terms of traditional environmental sociology

ment. In the case of environmental sociology, we are dealing here directly with the study of the impact of the natural environment on the human environment and all kinds of problems and related issues, studied within the mentioned areas. As part of this branch of sociology, the environment is recognized here as a social or socio-cultural environment, including the physical and spatial environment of a human being and the natural environment. It can, therefore, be concluded that the concept of the environment from the perspective of environmental sociology - is a social environment plus a physical environment plus a natural environment, which is the background of the occurrence of relevant social problems. This type of philosophy (vision) of perceiving the human environment could be graphically presented in the following two ways (see Figures $2 \mathrm{a}$ and $2 \mathrm{~b}$ ).

However, given the perception of the relationship between society and the natural environment, environmental sociology can also be interpreted in two ways: narrower and broader. In the narrower approach, which is currently dominant, the natural environment is perceived as an element affecting social life, including every human being (so it is, to a certain extent, an active element). The natural environment is, however, recognized as something detached from the social environment, and it does not allow capturing the full dynamics of that environment and - most importantly - it distorts the image of perception of the overall human environment and the vital role of nature in it. Hence the ideas to build a new

\footnotetext{
${ }^{4}$ This type of thought can be illustrated in variants of Figures $3 \mathrm{a}$ and $3 \mathrm{~b}$, in which blue (symbolizing nature) and yellow (symbolizing society) are combined (mixed) and give green, which figuratively shows the overall human life environment. In contrast, in traditional environmental sociology (or in environmental social psychology), the
}

and more complete systemic model of environmental sociology (interpreted more widely than today) (e.g., Bowden, 2017: 5) or another broader perspective created from the borderline between social and environmental sciences, highlighting the interrelated psychosocial and natural conditions of the human environment (e.g., Ciszek, 2009: 95-99; Ciszek, 2013).

In such a vision, the socio-cultural environment is perceived as built-up over the natural environment, and somehow embedded in it (see Figures $3 \mathrm{a}$ and $3 b)^{4}$. Nature is not only a habitat, but an active foundation on which the biological functioning of the social world is based, and more. This approach is legitimate because, in order for life to exist at all, lifegiving nature had to be created first, which still maintains human life, gives people a place to live; people also derive food, energy and all animated and inanimate vital elements from it, indispensable to individual and social existence and further development. Nature is here an active element (and not just a static space occupied and transformed by human populations), and what should be emphasized, also affecting various non-biological aspects of the social world, as well as specific cultural processes. For example, the specificity of the natural environment affects the development of various forms of material and non-material culture of people (e.g., the creation and development of sailing culture in coastal countries) (Ciszek, 2009: 95-99; Ciszek, 2013: 176-182, 194). Therefore, people live in a socio-natural envi-

natural biophysical environment was not treated as an integral part of the human environment, but as a relatively active habitat for social phenomena occurring within it, i.e., as two overlapping, but separated two-colored planes (Bowden, 2017: 5). 

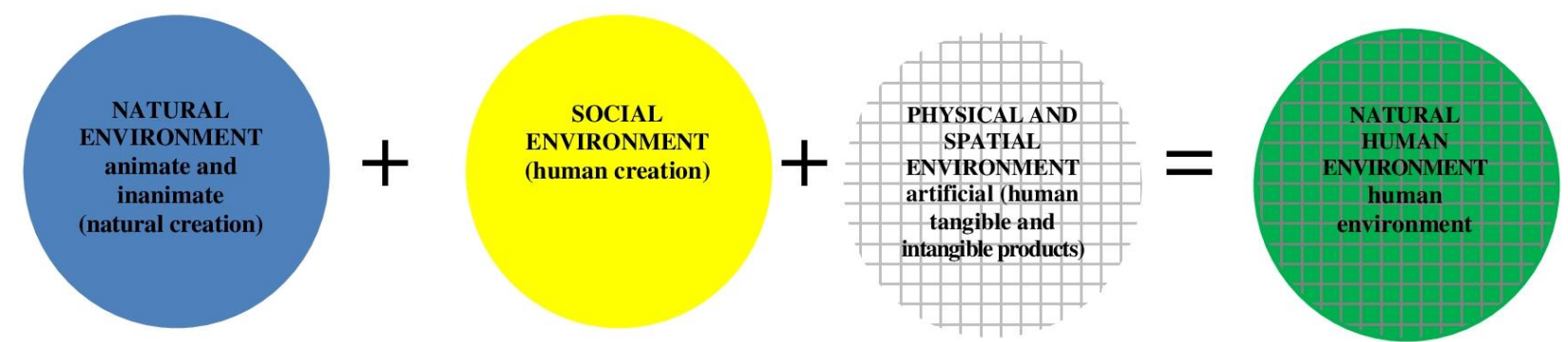

Figure 3a. The human socio-natural environment in terms of the postulated model of environmental sociology and psychology (psychosocial foundations of environmental security), source: author's own study
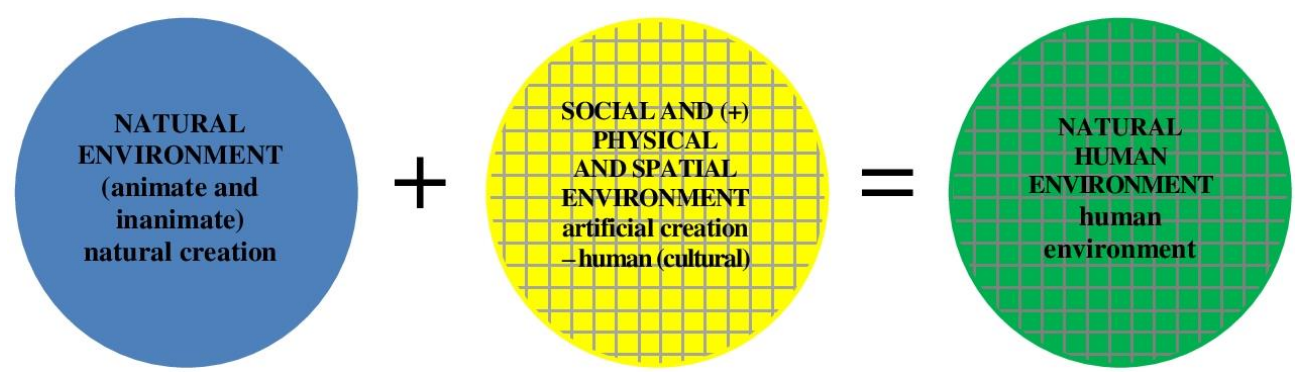

Figure 3b. The human socio-natural environment in terms of the postulated model of environmental sociology and psychology (psychosocial foundations of environmental security, source: author's won study

ronment, and not only in a social environment (e.g., Dołęga, 2003: 7-10; Bubolz and Sontag, 1993: 419448). Consequently, one should speak about a holistically and systemically understood socio-culturalnatural environment, and not just a narrowly defined social environment that affects the human social world and the life of each of us (Ciszek, 2013).

To sum up, environmental sociology studies interactions with the biophysical environment (animate and inanimate), but it does so in a rather separable way, unlike environmental psychology. Environmental psychologists have rightly pointed out that people should be studied in their natural living environment within which they are embedded, but the problem is that they have focused on physical and spatial issues of the social environment (see Fig. 1). It is, therefore, necessary to combine the psychological and sociological approach (see Figures 2a and 2b) and study the natural human environment taking into account natural aspects that are inseparably fused with the social environment (see Figures 3a and 3b).

More and more often, there are demands for such supplementation of sociological knowledge with knowledge in the field of ecology, which would enable environmental sociology to be transformed into ecological sociology. It would use not only sociological theories but also those in the field of ecology. It could examine, e.g., the impact of changes and evolution in the natural environment on the development and evolution of human societies (as specific socioecological and adaptive systems), while using the achievements of ecology as a biological science (Bowden, 2017: 2-14; Bowden, 2018), linking them with the need to protect the environment. This type of approach could be complemented especially by the achievements of interdisciplinary (natural and social) human ecology, which has been successfully developed for many years in Poland (e.g., Wolański, 2008).

Given such a broadly interpreted vision of environmental sociology, it can be said that the overall human environment consists of two broadly understood and systemically related environments: the natural environment (a product of nature) and the social environment embedded in it, surrounded by a physical and spatial environment (i.e., a socio-cultural product of a human being). At the same time, the natural environment is one essential component that is a product of nature. In contrast, the other social and physical environments make up the other component - artificial, being the result of socio-cultural human activity (in the material and non-material sphere), which could be considered in the ecological sense a non-biological way of a human being adapting to the surrounding environment. What is more, human activity in the field of culture affects not only the social but also the natural environment. Only this natural element plus the artificial (human or socio-cultural) element integrated with it constitute the natural human environment (see Figures 3a and 3b). For wild plants or animals, nature is their natural environment, while in the case of people - the natural environment is not only nature but also their artificial (socio-cultural) environment, which was created based on nature transformed by them and adapted to their needs (and total conditions). For a human being as an organism belongs to nature (being subject to natural laws). At the same time, as a social being and, above all, as a human person belongs to the social and cultural environment to which he/she is subject (social and cultural laws and rules), but at the same time is its autonomous creator (he/she is therefore 
not only the object of this environment's influence but above all the subject) ${ }^{5}$. Indeed, without nature, there would be no human, but without culture, there would be no human person. It can be concluded from such the philosophy of environment that in the case of people, both types of environments need to be protected. Then we will guarantee ourselves and world security, or, more specifically, environmental (ecological) security (Ciszek, 2013: 229-237). We touch upon here with the issue of environmental security, also called ecological security (and health security associated with it).

\section{Socio-natural environment and sustainable hu- man security (environmental and health security)}

The vision of the human environment from the perspective of environmental sociology discussed here, as well as previously characterized environmental social psychology, very well fits into the currently important issue and problem, which is ensuring environmental (ecological) security.

This variation of security can be defined as a permanent state free (of negative effects) of threats that violate the dynamic balance in the natural (socio-natural) environment, enabling (positive) ability to maintain it continuously, ensuring the existence, further development and a sense of such state 6 (own definition).

According to the definition of environmental (ecological) security and comments made before, the natural and artificial environment (human or socio-cultural) only taken together constitute the natural environment of human life - the human person (human environment). As a result, it is necessary to ensure such conditions of development in the political and socio-economic sphere of human civilization that the two dynamic elements - natural (creation of nature) and artificial (human creation) - remain in relative dynamic balance (see Figure $3 a$ and $3 b$ ). Such a desirable condition could be considered synonymous with homeostasis. On the other hand, disturbing this balance in favor of either of these two factors will always prove detrimental (unfavorable) for human security. Nevertheless, trends maintaining this balance will prove to be positive (beneficial) for human security in the long run (even when they entail some restrictions on development or generate significant financial outlays). This principle should form the basis for the development of the concept known as sustainable development, in which environmental security fits very well. For a human being needs for life and further development

\footnotetext{
${ }^{5}$ People, through the help of culture, mastered nature, without which they cannot survive, but at the same time crossed the world of nature, opening themselves to a new horizon of being - a sphere of the human spirit that prevents them from returning to nature in pure form (strictly biological, impersonal). Therefore, people cannot be reduced to biological beings that are part of nature. Besides,
}

a culturally transformed natural environment tailored to his/her needs, which entails the destruction of its resources. However, the destruction must be rationally justified and strictly controlled, because an excessively transformed and destroyed natural environment can lead to a barrier of civilization development and, in an extreme case, even annihilation of humanity. It is also worth preserving the wild deposits of natural heritage. The human social environment is not in a vacuum but is built up and embedded in (animate and inanimate) nature (Ciszek, 2013: 235). Therefore, any realistic concept of environmental security should have a sustainable dimension. In the concept of sustainable environmental security understood in this way, taking into account both natural and artificial elements of the human environment, in addition to strictly ecological (natural) conditions, there are also psychosocial ones. It is not surprising since the human life environment is a socionatural environment (Ciszek, 2018). Achievements in the field of environmental social psychology and environmental sociology (next to natural sciences) may contribute to research on environmental security and the development of a more comprehensive and sustainable concept. These environmental social sciences show the role and impact of the physical and natural environment on the functioning of the human psyche and personality as well as the behavior of people and the social world they create. These can also contribute to shaping ecological awareness and pro-environmental attitudes, and it will have a positive impact on the state of the environment and an appropriate level of security, which in the case of people is conditioned by both complex and related natural and psychosocial factors.

It is worth mentioning that the concept of environmental security presented above also integrates issues of human health (health security). The ecological balance in the socio-natural environment in a proper way affects the health of the individual and the entire population (society). Therefore, environmental security is conducive to protecting and shaping human health (and can and even should be treated as its vested interest - Ciszek, 2017). It is difficult to effectively implement any vision of health security without first ensuring the appropriate quality of the environment surrounding a human being (environmental security is a necessary condition for health security). Therefore, health security is an effect of environmental security, oriented after all on maintaining existence and further development, which in the case of people, always concerns their life and health. It can even be stated that such (bro-

people at the current stage of their development are strictly dependent on the socio-cultural environment.

${ }^{6}$ On the other hand, security (general security) could be defined as a permanent state free (of negative effects) of threats, enabling a beneficial ability to maintain it continuously, ensuring the existence, further development and a sense of such state (own definition). 


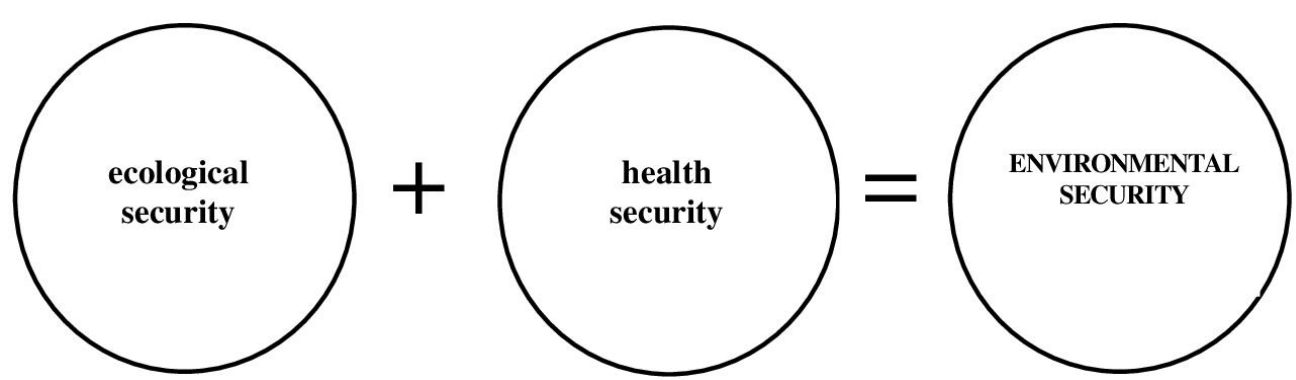

Figure 4. Components of broadly understood environmental security, source: author's own study

adly) perceived environmental security consists of (narrowly taken) ecological security (understood as protection and shaping of the natural environment) and health security (protection and shaping of human health) - see Fig. 4. Although many authors use the term environmental and ecological security interchangeably, this distinction is also possible and correct. After all, such broadly understood environmental security (as ecological and health security) very well fits into its definition previously formulated. It could be supplemented (by the expression in brackets) as a permanent state free (of adverse effects) of threats that violate the dynamic balance in the natural (socio-natural) environment, enabling (positive) ability to maintain it continuously, ensuring the existence, further development (including health and life $e^{7}$ and a sense of such state (own definition).

\section{Conclusions}

To sum up, this article shows that the human environment is not only a narrowly understood psychosocial, social or socio-cultural environment (as social psychologists or sociologists usually claimed) or a shallowly understood natural environment (as biologists perceived it), but a comprehensively understood socio-natural environment. Only such a broadly perceived environment in the case of people as both natural and social beings, or more precisely persons (psychophysical beings), is suitable for their natural living environment. Therefore, it should be recognized that any natural or psychosocial reductionisms hamper the proper and multidimensional understanding of the specificity of the human environment. It also applies to issues related to the development of sustainable environmental security, which we will never provide to people if we do not simultaneously take care of these two essential and inseparably integrated components of the human life environment. Namely, its natural plane (as a product of

${ }^{7}$ It should be borne in mind that existence is a broader concept than life (which may be included in it). For existence concerns not only living beings (e.g., human or other organisms) but also inanimate beings (the existence of inorganic elements of nature necessary for its functioning). Health on the other hand, is closely related to the concepts nature) and the socio-cultural dimension (artificial product of human being), blended into nature transformed for human needs. When a balance is maintained between these components, then we will ensure a sustainable level of environmental security and an appropriate level of optimal development for currently living people and their next generations. This type of environmental (ecological and health) security concept also fits very well with the idea of sustainable development. Moreover, nothing prevents it from being undertaken as one of the branches of environmental sociology (or environmental social psychology) or as an area independent of it, although closely related to it.

\section{References}

1. ALLPORT F. H., 1924, Social Psychology, Houghton Mifflin Company, Boston, New York.

2. BAŃKA A., 2002, Spoleczna psychologia środowiskowa, Wydaw. Naukowe SCHOLAR, Warsaw.

3. BARKER R. G., 1968, Ecological Psychology: Concepts and Methods for Studying the Environment of Human Behavior, Stanford University Press, Stanford.

4. BARKER R. G. and Associates, 1978, Habitats, Environments, and Human Behavior [studies in ecological psychology and eco-behavioral science from the Midwest Psychological Field Station, 1947-1972], Jossey-Bass Publishers, San Francisco.

5. BARKER R. G., 1987, Prospecting in Environmental Psychology, in: Handbook of Environmental Psychology, eds. Stokols D. and Altman I., Wiley, New York, vol. 2, p. 1413-1432.

6. BELL M. M., ASHWOOD L. L., 2016, An Invitation to Environmental Sociology, 5th ed., SAGE Publications Ltd, Thousand Oaks

7. BELL P. A., GREENE T. C., FISHER J. D., BAUM A., 2001, Environmental Psychology, 5th Edition, Harcourt College Publishers, New York.

8. BIELAK M., 2012, Research Methods Aiding the Creation of the Built, in: Architecture Civil Engineering Environment, no 3, p. 5-17.

of life and development (often contained in them), because its lack or illness hinders life and optimal development of human being (organism), and can even lead to his/her death (non-being); and in the positive version - health is conducive to life support and development. 
9. BOWDEN G., 2017, From Environmental to Ecological Sociology, in: TASA: The Australian Sociological Association, https://tasa.org.au/wp-content/uploa ds/2011/01/BOWDEN_a.pdf, p.1-14 (20.12.2017).

10. BOWDEN G., 2018, Environmental Sociology (Gary Bowden - Feature Profile: posted on September 20, 2012), in: Environment Cluster: Canadian Sociological Association, http://www.csa-scs.ca/files/webapp s/csapress/environment/? $\mathrm{p}=135$ (3.01.2018).

11. BUBOLZ M. M., SONTAG M. S., 1993, Human Ecology Theory, in: Sourcebook of Family Theories and Methods: A Contextual Approach, eds. Boss P. G., Doherty W. J., LaRossa R., Schumm W. R. and Steinmetz S. K., Plenum Press, New York, p. 419448.

12. BURNS T., CANIGLIA B., 2015, Environmental Sociology, in: Oxford Bibliographies, http://www. oxfordbibliographies.com/view/document/obo-9780 199756384/obo-9780199756384-0117.xml (10.03.2015).

13. CANTER D., 1988, Environmental (Social) Psychology: An Emerging Synthesis, in: Environmental Social Psychology. Proceedings of the NATO advanced research workshop on social and environmental psychology in the European Context (Lisbon, Portugal, September 1986), from NATO ASI Series, Series D: Behavioural and Social Sciences, vol. 45, eds. Canter D., Jesuino J. C., Soczka L. and Stephenson G. M., Published in cooperation with NATO Scientific Affairs Division, Kluwer Academic Publishers, Dordrecht, Boston, London, p. 1-18.

14. CAROLAN M., 2017, Society and the Environment: Pragmatic Solutions to Ecological Issues, 2nd ed., Westview Press, Boulder.

15. CATTON W. R., DUNLAP R. E., 1978, Environmental Sociology: A New Paradigm, in: The American Sociologist, 13, p. 41-49.

16. CISZEK M., 2009, Środowisko naturalne człowieka jako aktywny czynnik zmiany społecznej. Perspektywa socjologiczno-ekologiczna, in: Doctrina. Studia Spoleczno-Polityczne, vol. 6, p. 95-99.

17. CISZEK M., 2013, Filozofia ekologii rodziny ludzkiej $w$ systemie środowiska spolecznego, kulturowego $i$ przyrodniczego: Studium społeczno-filozoficzne z zakresu bezpieczeństwa ekologicznego, Wydaw. Uniwersytetu Przyrodniczo-Humanistycznego w Siedlcach, Siedlce.

18. CISZEK M., 2017, Bezpieczeństwo ekologiczne ważny czy żywotny interes narodowy? (perspektywa całościowa), in: Studia Ecologiae et Bioethicae, 15 (2).

19. CISZEK M., 2018, Las jako element środowiska społeczno-przyrodniczego i jego funkcje społecznokulturowe (paper presented during the 11th National Scientific Conference of the 'Humanities Ecology' series, entitled 'Forest for People - People for Forest', Warsaw IEiB UKSW April 12, 2018), in: https:// ieib.edu.pl/historia-konferencji/.

20. COLE N. L., 2017, All About Environmental Sociology: A Brief Introduction to the Subfield, in: ThoughtCo, https://www.thoughtco.com/environmen tal-sociology-3026290 (6.03.2017).

21. CZARTOSZEWSKI J. W. (ed.), 2003, Konflikty społeczno-ekologiczne, VERBINUM Wydaw. Księży Werbistów, Warsaw.
22. DOŁĘGA J. M., 2003, Słowo o środowisku społeczno-przyrodniczym, in: Wychowanie do poszanowania środowiska spoleczno-przyrodniczego, ed. Czartoszewski J. W. and Kotowski J. M., VERBINUM Wydaw. Księży Werbistów, Warsaw, p. 7-10.

23. GIBSON J. J., 1972, The Affordances of the Environment, in: Reasons for Realism: Selected Essays of James J. Gibson, eds. Reed E. and Jones R., Lawrence Erlbaum Associaties, Hillsdale, p. 408-410.

24. GIBSON J. J., 1977, The Theory of Affordances, in: Perceiving, Acting, and Knowing: Toward an Ecological Psychology, eds. Shaw R. and Bransford J., Lawrence Erlbaum Associaties, Hillsdale, p. 67-82.

25. GIBSON J. J., 1979, The Ecological Approach to Visual Perception, Houghton Mifflin, Boston.

26. GIFFORD R., 2014, Environmental Psychology: Principles and Practice, 5th ed., Optimal Books, Colville .

27. GIFFORD R. (ed.), 2016, Research Methods for Environmental Psychology, Wiley Blackwell, West Sussex.

28. GOULD K. A., LEWIS T. L., 2015, Twenty Lessons in Environmental Sociology, 2nd ed., Oxford University Press, New York.

29. GROSS M., HEINRICHS H. (eds.), 2010, Environmental Sociology: European Perspectives and Interdisciplinary Challenges, Springer, Dordrech, New York.

30. HANNIGAN J., 2014, Environmental Sociology, 3rd ed., Routledge/ Taylor \& Francis Group, London, New York.

31. IRWIN A., 2001, Sociology and the Environment: A Critical Introduction to Society, Nature, and Knowledge, Polity Press/ Blackwell Publishers, Cambridge, Oxford, Malden.

32. KING L., McCARTHY AURIFFEILLE D. (eds.), 2014, Environmental Sociology: From Analysis to Action, 3rd ed., Rowman \& Littlefield Publishers, Lanham.

33. KOGER S. M., WINTER D. D. N., 2010, The Psychology of Environmental Problems: Psychology for Sustainability, 3rd ed., Psychology Press, New York (Chapter 4: Social Psychology: Under the Influence of Others Norms, p. 95-130).

34. LUBISZEWSKI D., 2012, Odnaleźć się w gąszczu ofert: psychologia ekologiczna dla bardzo początkujących, in: AVANT. Pismo awangardy filozoficznonaukowej, 3(2), p. 267-270.

35. MARTELL L., 1994, Ecology and Society: An Introduction, University of Massachusetts Press, Amherst.

36. MATCZAK P., 2000, Problemy ekologiczne jako problemy spoteczne, Wydaw. Naukowe Uniwersytetu im. A. Mickiewicza, Poznań.

37. MATCZAK P., 2001, Lokalne protesty na tle ochrony środowiska, in: Konflikt nieunikniony: spoteczności $i$ wtadze lokalne wobec konfliktów spowodowanych rozwojem, eds. Buczkowski P. i Matczak P., Wydaw. Wyższej Szkoły Bankowej, Poznań, p. 59-65.

38. MAZURSKI K. R., 2009, Środowisko, in: Stownik bioetyki, biopolityki i ekofilozofii (w kręgu zagadnień i moralnych problemów bezpieczeństwa), ed. Ciszek M., PTF, Warsaw, p. 260.

39. OLACZEK R., 1999, Stownik szkolny. Ochrona przyrody i środowiska, WSiP, Warsaw. 
40. OLECHNICKI K., ZAŁĘCKI P., 2002, Stownik socjologiczny, Wydaw. Graffiti BC, Torun.

41. REDCLIFT M., BENTON T. (eds.), 1994, Social Theory and the Global Environment, Routledge, London, New York.

42. REDCLIFT M. R., WOODGATE G. (eds.), 2010, The International Handbook of Environmental Sociology, 2nd ed., Edward Elgar Publishing, Cheltenham, Northampton.

43. SABOURIN M., LAMARCHE L., 2009, Environmental Social Psychology, in: Psychology [from Encyclopedia of Life Support Systems (EOLSS). Developed under the Auspices of the UNESCO], ed. Carta S., Eolss Publishers, Oxford, vol. 1, p. 218234.
44. SCHNAIBERG A., GOULD K. A., 1994, Environment and Society: The Enduring Conflict, St. Martin's Press, New York.

45. STEG L., BERG van den A. E., GROOT de J. I. M (eds.), 2012, Environmental Psychology: An Introduction, Wiley-Blackwell, Chichester, Malden.

46. STOKOLS D., ALTMAN I., (eds.), 1987, Handbook of Environmental Psychology, John Wiley \& Sons, New York.

47. WINTER D. D. N., 1986, Ecological Psychology: Healing the Split Between Planet and Self, HarperCollins College Publishers, New York.

48. WOLAŃSKI N., 2008, Ekologia człowieka, vol. 2, Ewolucja i dostosowanie biokulturowe, PWN, Warsaw. 